\title{
AOR
}

Selected Papers of \#AolR2021:

The 22nd Annual Conference of the

Association of Internet Researchers

Virtual Event / 13-16 Oct 2021

\section{BODIES AND DATA: THE DIGITAL SOVEREIGNTY OF THE INDIAN STATE}

\author{
Revati Prasad, Institute for Local Self Reliance \\ In February 2019, the Government of India released a draft e-commerce policy that \\ boldly proclaimed, "India and its citizens have a sovereign right to their data," \\ (Department for Promotion of Industry and Internal Trade, 2019). The draft policy was \\ one of many in recent years that have mandated data localization, protectionism or \\ other measures of greater national control over the digital economy in India. These \\ actions are widely read in geopolitical terms as a nation-state asserting its sovereignty \\ in the digital realm against US-based global tech firms, a digital sovereignty that \\ challenges digital colonialism. I argue that the Indian state's project of digital \\ sovereignty must also be understood as biopolitical.
}

I connect the Indian state's regulation of the digital economy, exemplified by the 2019 draft of the e-commerce policy to its regulation and control of bodies, specifically through the biometric ID, Aadhaar, and its proliferating uses. I read these state actions collectively as a project through which the Indian state is engaged in altering what it is to be sovereign and its subject. When "digital" appends sovereignty, it is not merely a new terrain upon which to exert power, nor is it an unbridled force that the state must contend with, it is the means through which the Indian state enacts its project(s) of domination.

First, I unpack the claims made about data in the document, namely that an individual owns the right to their data, that data is analogous to a natural resource like coal, and that Indian data can and should be thought of as a "societal commons" held in trust by the government. I also address how the policy engages with the global discourse on data ownership and protection. In order to stake a national claim to the data produced in India, the policy begins at an individual level, arguing that because data derives from individuals' actions, they own the rights to it. Despite appearances, this is not an ownership claim. The policy offers no avenue for an individual to exercise these rights outside of the state, and the only group identity the policy acknowledges is nationality. In ascribing value to data, the policy reaches for the increasingly common resource extraction metaphor, data as coal or data as oil. Having established that data derives from individuals and that it has value, the policy then touts India's ability to create this value. As the second most populous country, with a young consumer society, the policy

\footnotetext{
Suggested Citation (APA): Prasad, R., (2021, October). Bodies and Data: The Digital Sovereignty if the Indian State. Paper presented at AolR 2021: The 22nd Annual Conference of the Association of Internet Researchers. Virtual Event: AolR. Retrieved from http://spir.aoir.org.
} 
states that India could yield a "virtual treasure trove of information" (Department for Promotion of Industry and Internal Trade, 2019). As the state lays claim to this data on behalf of individual Indians, the resource being monetized is not simply data, but the country's populace.

To this end, the policy also points to the state's own sources of data, in particular Aadhaar, through which the state has concertedly worked to digitize our lives and interactions. Aadhaar was proposed as convenient paperless identification for citizens to avail government benefits, but over the course of the last decade and through extraordinary and arguably extralegal state action, it is now mandatory for a range of public and private services from filing taxes to opening bank accounts to taking school exams (Bhatia \& Bhabha, 2017). As Aadhaar pervaded every aspect of life, it was consistently opposed along the way, culminating in a 2018 Supreme Court case that challenged the project's constitutionality. I draw on the argumentation against Aadhaar at the court to elaborate on what Ajana (2013) has termed "biometric citizenship."

Agamben (1998) argued that the exceptional figure of Homo Sacer, the outcast who can be killed without punishment but not sacrificed, is the most elementary operation of sovereign power. Ajana built on Agamben's biopolitical notion of sovereignty to argue that biometric systems expand "the mechanisms by which what was once confined to 'exceptional' spaces and practices is now in the process of becoming a permanent rule by spilling over to the biopolitical body of humanity as a whole" (Ajana, 2013, p. 45). Lawyers opposing Aadhaar highlighted cases of exclusion, resulting from technical failures, fraud or simply the probabilistic nature of biometrics, and the dire outcomes of Aadhaar's vicissitudes. Aadhaar's mandatory nature made citizenship conditional by undermining bodily autonomy, extending a state of exception, and expelling some bodies. One lawyer called to mind Agamben's Homo Sacer, when he said Aadhaar could cause a citizen's "civil death" (Divan, 2018).

The project of digital sovereignty consolidates the power of the Indian state. Whether it is through data localization measures, or the proliferating uses of biometric ID to digitize ever more social, economic and political interactions, it is a concerted effort that grants the state unprecedented access to the bodies and lives of the people in India. It compels the creation of a certain type of data and then claims that data as belonging, not to the individuals, but to the state. It uses the discourse of "data sovereignty" to establish foreign tech companies as a foil and deflects attention away from its domestic implications.

A popular understanding of sovereignty is supreme authority within bounded territory. Brown argued that sovereignty is founded through enclosure, "it is through the walling off of space from the common that sovereignty is born" (Brown, 2014, p. 48). Pointing to the colonial histories of sovereignty, Bonilla (2017) argued sovereignty cannot be understood divorced from "material practices of dispossession" (p. 232). Andrejevic (2007) drew a parallel between the land enclosure movement of eighteenth-century England and the commodification of our online activities to propose "digital enclosure". Andrejevic's conception of digital enclosure focused on commercial actors, but when read along with the historic relationship between enclosure and sovereignty, it sheds light on the practices of appropriation central to India's project of digital sovereignty. 
In this project, the state uses its coercive power and enacts the logic of capital. While the claims of data sovereignty gesture towards the geopolitical, the biopolitical work of Aadhaar expands dominion within national borders. Together, these form India's project of digital sovereignty. By identifying this as a project, I call attention to the ongoing work by the state to naturalize a set of interrelated claims about technology, data and the role of the state and give them material force through government actions. Identifying digital sovereignty as a project, underscores that it is still unfolding and as such is open to contestation and challenge.

\section{References}

Agamben, G. (1998). Homo Sacer: Sovereign Power and Bare Life. Stanford University Press.

Ajana, B. (2013). Governing through Biometrics: The Biopolitics of Identity. Palgrave Macmillan.

Andrejevic, M. (2007). Surveillance in the Digital Enclosure. The Communication Review, 10(4), 295-317. https://doi.org/10.1080/10714420701715365

Bhatia, A., \& Bhabha, J. (2017). India's Aadhaar scheme and the promise of inclusive social protection. Oxford Development Studies, 45(1), 64-79.

https://doi.org/10.1080/13600818.2016.1263726

Bonilla, Y. (2017). Unsettling Sovereignty. Cultural Anthropology, 32(3), 330-339. https://doi.org/10.14506/ca32.3.02

Brown, W. (2014). Walled States, Waning Sovereignty. Zone Books.

Department for Promotion of Industry and Internal Trade. (2019). Draft National eCommerce Policy: India's Data for India's Development.

https://dipp.gov.in/sites/default/files/DraftNational_ecommerce_Policy_23February2019.pdf

Divan, S. Opening Statement on Behalf of The Petitioners, Writ Petition (Civil) No. 829 of 2013, Supreme Court of India (2018). 